\title{
Multi-drug resistant and extended-spectrum $\beta$-lactamases producing bacterial uropathogens among pregnant women in Northwest Ethiopia
}

\author{
Sirak Biset ${ }^{*}$ (1), Feleke Moges, Demeke Endalamaw and Setegn Eshetie
}

\begin{abstract}
Introduction: Above $80 \%$ of urinary tract infections are caused by enteric bacteria, which are known for years by their drug-resistant ability. Though the prevalence of drug-resistant strains is increasing in the world, it is not well known in low-income countries. The aim of this study was to assess the prevalence of Multi-drug resistance, Extended-spectrum $\beta$-lactamases production, and associated risk factors among pregnant women in Northwest Ethiopia.

Methods: A hospital-based cross-sectional study was conducted among pregnant women from March to May 2017. A total of 384 clean-catch midstream urine sample was collected from study participants. Bacterial identification and drug susceptibility testing were done following standard microbiological techniques; Extended-spectrum $\beta$-lactamase production was screened using a disc diffusion test and confirmed by a combination disc test. The data were entered and analyzed by using SPSS version 20 , and a p-value of less than 0.05 was considered as statistically significant.
\end{abstract}

Result: The overall prevalence of urinary tract infection was 15.9\% (95\% Cl 12.8-20.1\%). E. coli (49.2\%), CoNS (27.9\%), and S. aureus (18\%) were the main uropathogens. The prevalence of MDR uropathogens was $60.65 \%$. The prevalence of ESBLs production among cases caused by Enterobacteriaceae was $18.2 \%$. The drug resistance rate of Gram-negative isolates was higher for ampicillin (90.9\%), cephalothin (84.8\%), and augmentin (57.6\%). The drug nitrofurantoin showed the highest activity (100\%) against Gram-negative isolates. Gram-positive isolates were showed low susceptibility to penicillin (89.3\%) and cotrimoxazole (75\%); however highest susceptibility rate for gentamicin (100\%), amikacin (100\%), and nitrofurantoin (98.36\%) was recorded. Prior antibiotic therapy (AOR $=5.46,95 \% \mathrm{Cl} 1.38-21.65$ ) was a risk factor for the presence of multi-drug resistant bacteria.

Conclusion and recommendation: The multi-drug resistance prevalence was high among uropathogen, thus treatment of urinary tract infection during pregnancy; should be based on the antibacterial susceptibility testing result. The isolation of drug-resistant strains like Extended-spectrum $\beta$-lactamases in this study calls for the need of periodic and continuous follow-up of antibiotic usage among pregnant women. Nitrofurantoin, gentamicin, amikacin, and ciprofloxacin/norfloxacin showed higher activity against bacterial uropathogen.

Keywords: Extended-spectrum $\beta$-lactamase, Multi-drug resistant, Pregnant women, Urinary tract infection

*Correspondence: serbis33@gmail.com Department of Medical Microbiology, College of Medicine and Health Sciences, University of Gondar, P.O. Box: 196 Gondar, Ethiopia

\section{Background check}

Urinary tract infection (UTI) is an infection involving urinary tract structures [1]. The urinary tract can be infected in different ways, but the ascent of bacteria from the urethra is the common pathway [2]. Urinary 
tract infection is the most common public health problem worldwide with women are more likely to be infected due to proximity of the urethral opening to the anus, the presence of vagina, and the shorter length of the urethra $[3,4]$. Furthermore, pregnancy facilitates UTIs because of urinary retention in the bladder, increased calyceal and ureteral dilation, and increased levels of urinary glucose and amino acids [5]. Urinary tract infection during pregnancy can cause many complications [6-8]. To prevent these complications, during pregnancy, UTI should be treated [7-12]. However, this high occurrence of UTI in pregnancy could increase the prevalence of inappropriate antibacterial treatment, which in turn increases antibiotic resistance (ABR) [13].

Antibiotic resistance is a growing problem across the world, and indiscriminate use of drugs increases its evolution $[14,15]$. It is known that antibiotics are used to clear infection causing bacteria, however, their usage increases the prevalence of antibiotic-resistant strains via selective pressure where antibiotics kill susceptible strains and leave the resistant one to multiply [16, 17]. Production of enzymes is a well-known mechanism that the bacteria are using to resist antibiotics $[18,19]$. Extended-spectrum $\beta$-lactamases (ES $\beta$ Ls) producing strains can easily hydrolyze $\beta$-lactam agents but inhibited by $\beta$-lactamase inhibitors [20]. These organisms also carry genes encoding resistance to other classes of antibiotics. As a result, most of them are classified as multidrug resistant (MDR) organisms [19]. The enzymes and other ABR determinants of a drug-resistant bacteria can also be transferred to drug-susceptible strains [21]. Furthermore, there is a report that these drug-resistant bacteria or genes codes for drug resistance can be transmitted vertically from mothers to their neonates [22]. Urinary tract infections during pregnancy are commonly caused by Gram-negative bacteria, with Enterobacteriaceae, in particular, E. coli accounted for about $90 \%$ of these infections [23]. During pregnancy, untreated UTIs or UTIs caused by MDR or drug-resistant strains like ES $\beta$ Ls are associated with many problems, including the development of pyelonephritis and cystitis in the mother, pre-eclampsia, preterm delivery, low birth weight infant, and cesarean deliveries [24-26]. Multi-drug resistant organisms are associated with history of hospitalization, previous use of any antibiotics, chronic underlying diseases, use of urinary catheters, and previous history of UTIs. [27].

In Ethiopia, UTI among pregnant women is very common with a reported prevalence between $9.2 \%$ and $18.8 \%$; Enterobacteriaceae are the leading isolates responsible for the infection [28-33]. The WHO global report has revealed the overall epidemiology of ES $\beta \mathrm{L}$ producing bacteria has not been well known in resource-limited countries like Ethiopia [34]. Therefore, this study was aimed at determining MDR and ES $\beta \mathrm{L}$ production in bacterial uropathogens isolated from pregnant women, and identifying associated risk factors for MDR bacterial infection.

\section{Methods}

\section{Study area, design and period}

A hospital-based cross-sectional study was conducted from March to May 2017 at the University of Gondar Hospital (UoGH), Northwest Ethiopia. This referral teaching hospital is one of the biggest hospitals in the Amhara region. About five million people, from the surrounding areas, visit this hospital for different medical services. The study population was pregnant women, who were not on antibiotic treatment for the last 2 weeks from the data collection day, visiting the ANC unit of the hospital.

\section{Sample size and sampling technique}

The sample size of this study was 384 . Since there is no clear data on the prevalence of ES $\beta$ Ls producing strains or MDR bacteria among pregnant women, a single population proportion formula, taking $\mathrm{p}$ as $50 \%$, was used to calculate the sample size. The systematic sampling technique was applied to select the study participants. Sampling interval was calculated from the sampling frame, estimated number of ANC attendants during the study period. The first study participant was selected using lottery method.

\section{Data collection procedure}

All the study participants were interviewed face to face by trained data collectors (midwives), using a structured and pretested questionnaire, to collect data on the sociodemographic, clinical, and pregnancy-related characteristics. Finally, instruction on how to collect clean-catch midstream urine samples was given to the pregnant women; 10-20 $\mathrm{ml}$ of urine specimen was collected using a sterile screw-capped, wide-mouthed container. The container was labeled with unique code, date, and time of collection then sent to the microbiology laboratory for processing and testing [35].

\section{Culture and identification technique}

The urine specimen was first inoculated on CysteineLactose-Electrolyte-Deficient (CLED) agar using a sterile loop measuring $10 \mu \mathrm{l}$ then later colonies from CLED agar were subjected to gram staining procedure and then subcultured on MacConkey and Blood agar plates (Oxoid, UK). The plates were incubated in the appropriate atmosphere at $37{ }^{\circ} \mathrm{C}$ for $24-48 \mathrm{~h}$ overnight. A colony count of $\geq 10^{5} \mathrm{CFU} / \mathrm{ml}$ of urine was considered as significant 
bacteriuria. The identification of the culture-grown bacteria was based on the gram staining, colony characteristics, and biochemical reactions [35]. The Analytical Profile Index (API 20E) was used to support the bacterial identification process (bioMerieux, France).

\section{Drug susceptibility testing (DST)}

Antibiotic susceptibility testing was carried out using the disc diffusion method. The bacterial suspension was made; its turbidity was adjusted to a 0.5 McFarland turbidity standard before inoculated over the entire surface of Muller Hinton agar [35]. In this study, the following antibiotic discs were used: for Gram-negative bacteria, ampicillin $(10 \mu \mathrm{g})$, cephalothin $(30 \mu \mathrm{g})$, nalidixic acid $(30 \mu \mathrm{g})$, cefepime $(30 \mu \mathrm{g})$, augmentin $(30 \mu \mathrm{g})$, ceftazidime $(30 \mu \mathrm{g})$, cefotaxime $(30 \mu \mathrm{g})$, cefixime $(5 \mu \mathrm{g})$, ceftriaxone $(30 \mu \mathrm{g})$, cefuroxime $(30 \mu \mathrm{g})$, and cefpodoxime $(10 \mu \mathrm{g})$; for gram-positive bacteria, cotrimoxazole $(1.25 / 23.75 \mu \mathrm{g})$, gentamicin $(10 \mu \mathrm{g})$, amikacin $(30 \mu \mathrm{g})$, tetracycline $(30 \mu \mathrm{g})$, chloramphenicol $(30 \mu \mathrm{g})$, doxycycline $(30 \mu \mathrm{g})$, penicillin (10 units), and erythromycin $(15 \mu \mathrm{g})$, and for both classes of bacteria, cefoxitin $(30 \mu \mathrm{g})$, norfloxacin $(10 \mu \mathrm{g})$, ciprofloxacin $(5 \mu \mathrm{g})$ and nitrofurantoin $(300 \mu \mathrm{g})$. The zone diameter was interpreted according to the Clinical and Laboratory Standards Institute (CLSI) [36]. Bacterial isolates were regarded as MDR when they were resistant to one or more antibiotics in three or more classes of antimicrobials that the isolate is expected to be susceptible.

\section{Extended-spectrum $\beta$-lactamases detection}

All isolates showing reduced susceptibility to either of the 3rd generation cephalosporins (Cefpodoxime zone: $\leq 17 \mathrm{~mm}$; Ceftazidime zone: $\leq 22 \mathrm{~mm}$; Cefotaxime zone: $\leq 27 \mathrm{~mm}$; Ceftriaxone zone: $\leq 25 \mathrm{~mm}$ ) were selected using disc diffusion method. Those isolates then subjected to a phenotypic confirmatory test for ES $\beta$ Ls detection [37]. A combination disc test was used based on CLSI 2017 recommendations [37]. Cefotaxime $(30 \mu \mathrm{g})$, ceftazidime $(30 \mu \mathrm{g})$, ceftazidime-clavulanate $(30 / 10 \mu \mathrm{g})$ and cefotaxime-clavulanate $(30 / 10 \mu \mathrm{g})$ discs were plated on MHA that was inoculated with a single bacterial suspension. After overnight incubation, $16-18 \mathrm{~h}$ at $37^{\circ} \mathrm{C}, \mathrm{a} \geq 5 \mathrm{~mm}$ increase in zone diameter of cefotaxime-clavulanate and/or ceftazidime-clavulanate than the zone diameter of cefotaxime and/or ceftazidime was taken as positive for the presence of ES $\beta$ Ls in bacterial isolates.

\section{Quality control}

A pre-tested and structured questionnaire was used to collect socio-demographic, pregnancy, and clinicalrelated factors. Standard Operating Procedures (SOPs) were strictly followed during all the stages of sample collection and laboratory work. Reference strains used in this study were $E$. coli ATCC 25922, P. aeruginosa ATCC 27853, and S. aureus ATCC 25923. The sterility of the prepared media was checked by incubating $5 \%$ of the batch overnight at $37{ }^{\circ} \mathrm{C}$. For ES $\beta \mathrm{L}$ positive control, $K$. pneumoniae ATCC 700603, and ES $\beta$ L negative control, $E$. coli ATCC 25922 strains were used [37].

\section{Data processing and analysis}

The data was entered into SPSS version 20 and was double-checked before analysis. Appropriate descriptive statistics for demographic, clinical, and pregnancy-related characteristics were calculated. The bivariable logistic regression model was fitted for each independent variable. Moreover, those variables having a $\mathrm{p}$-value $<0.2$ in univariate analysis were fitted into the multivariable logistic regression model. Odds ratio with a $95 \%$ confidence interval and p-values were used to measure the strength of association and to identify statistically significant associated factors, respectively. In multivariable analysis, variables having a $\mathrm{p}$-value $<0.05$ were considered to have a statistically significant association with MDR bacterial infection.

\section{Results}

\section{Socio-demographic characteristics}

A total of 384 pregnant women were participated in the present study with the age ranges of 15-45 and a mean (standard deviation) age of $26( \pm 5.4)$. About 349 (90.9\%) of the study participants were Orthodox Christians, 305 (79.4\%) were urban, and 365 (95\%) were married. About 128 (33\%) of the participants were illiterate, 167 (43.5\%) were housewives, and 110 (28.6\%) had monthly income $\leq 1000$ birr (Table 1 ).

\section{Pregnancy and clinical related factors}

Among the study participants, 190 (49.5\%) and 119 (31\%) were on their 3rd and 2nd trimester, respectively. Based on parity, $224(58.3 \%)$ of the women had more than one pregnancy experience, and 176 (45.8\%) of them were nulliparous. Of the total study participants, $26(6.8 \%)$ had a history of prior hospitalization, 62 (16.1\%) had a history of previous UTI, and 88 (22.9\%) had prior antibiotic therapy. 3.4\% of pregnant women had HIV infection. The number of pregnant women with a symptom/s of UTI was $122(31.8 \%)$ (Table 2$)$.

\section{Prevalence of urinary tract infection among the study group}

The overall prevalence of UTI among study participants was 61 (15.9\% (95\% CI 12.8-20.1\%)). Of isolated uropathogens, E. coli 30 (49.2\%) was the commonest uropathogen, followed by CoNS 17 (27.9\%) and S. aureus 11 (18\%). 
Table 1 Socio demographic characteristics of the study groups

\begin{tabular}{|c|c|c|}
\hline Socio-demographic characteristics & Frequency & Percentage \\
\hline \multicolumn{3}{|l|}{ Age (in years) } \\
\hline $15-19$ & 21 & 5.5 \\
\hline $20-24$ & 127 & 33.1 \\
\hline $25-29$ & 141 & 36.7 \\
\hline $30-34$ & 51 & 13.3 \\
\hline$>34$ & 44 & 11.5 \\
\hline \multicolumn{3}{|l|}{ Religion } \\
\hline Orthodox & 349 & 90.9 \\
\hline Muslim & 31 & 8.1 \\
\hline Protestant & 2 & 0.5 \\
\hline Others & 2 & 0.5 \\
\hline \multicolumn{3}{|l|}{ Residence } \\
\hline Urban & 305 & 79.4 \\
\hline Rural & 79 & 20.6 \\
\hline \multicolumn{3}{|l|}{ Marital status } \\
\hline Currently single & 19 & 4.9 \\
\hline Currently married & 365 & 95.1 \\
\hline \multicolumn{3}{|l|}{ Level of education } \\
\hline Not read and write & 128 & 33.3 \\
\hline Primary & 71 & 18.5 \\
\hline Secondary & 99 & 25.8 \\
\hline College/university & 86 & 22.4 \\
\hline \multicolumn{3}{|l|}{ Occupation } \\
\hline House wife & 167 & 43.5 \\
\hline Farmer & 37 & 9.6 \\
\hline Merchant & 46 & 12 \\
\hline Employed & 96 & 25 \\
\hline Daily labourer & 21 & 5.5 \\
\hline Others & 17 & 4.4 \\
\hline \multicolumn{3}{|l|}{ Monthly income (in birr) } \\
\hline$\leq 1000$ & 110 & 28.6 \\
\hline $1000-1800$ & 86 & 22.4 \\
\hline $1801-2800$ & 98 & 25.5 \\
\hline$\geq 2801$ & 90 & 23.4 \\
\hline
\end{tabular}

The prevalence of MDR among uropathogens was 37 (60.65\%). About 13 (76.47\%) of the CoNS and 17 (56.67\%) of the $E$. coli isolates were MDR. The prevalence of ES $\beta$ Ls production among Enterobacteriaceae was 6 (18.2\%). E. coli and Enterobacter cloacae were the two ES $\beta$ L producing isolates. Among Gram-positive isolates, $4(36.36 \%)$ of the $S$. aureus were MRSA, and 8 (47.06\%) of the CoNS were resistant to methicillin (Table 3).

The prevalence of UTI among symptomatic and asymptomatic cases was 38/122 (31.1\%) and 23/262 $(8.8 \%)$, respectively. The Fisher's exact test showed that history of hospitalization, previous history of UTI, and

\begin{tabular}{|c|c|c|}
\hline Pregnancy related characteristics & Frequency & Percentage \\
\hline \multicolumn{3}{|l|}{ Gestation period } \\
\hline$<3$ months & 55 & 14.3 \\
\hline $3-6$ months & 119 & 31 \\
\hline$>6$ months & 190 & 49.5 \\
\hline Don't know & 20 & 5.2 \\
\hline \multicolumn{3}{|l|}{ No of pregnancy } \\
\hline Prim-gravida & 160 & 41.7 \\
\hline Multi-gravida & 224 & 58.3 \\
\hline \multicolumn{3}{|l|}{ No of times giving birth } \\
\hline Nulliparous & 176 & 45.8 \\
\hline Primiparous & 98 & 25.5 \\
\hline Multiparous & 110 & 28.6 \\
\hline Previous hospitalization & 26 & 6.8 \\
\hline History of UTI & 62 & 16.1 \\
\hline Antibiotic therapy & 88 & 22.9 \\
\hline HIV positive & 13 & 3.4 \\
\hline \multicolumn{3}{|l|}{ Participant status for UTI } \\
\hline Symptomatic & 122 & 31.8 \\
\hline Asymptomatic & 262 & 68.2 \\
\hline
\end{tabular}

prior antibiotic therapy were associated with the presence of UTI. The prevalence of MDR bacteria was 25/38 (65.8\%) and 12/23 (52.2\%) among culture-positive symptomatic and asymptomatic participants, respectively. The prevalence of MDR was significantly higher $(\mathrm{p}<0.05)$ among study participants who had a history of antibiotic therapy than those who hadn't. (Table 4).

\section{Antimicrobial susceptibility pattern}

Only 2/61 (3.28\%) of bacterial isolates were sensitive to all antibiotics used in this study. The 14 (22.95\%), 16 (26.23\%), and 19 (31.15\%) of the isolates were resistant to two, three, and at least five of the antibiotics tested, respectively (Table 5).

A high number of $E$. coli isolates were resistant to ampicillin 27 (90\%), cephalothin $25(83.33 \%)$, and augmentin 17 (56.7\%). None of the Gram-negative isolates were resistant to nitrofurantoin, and none of the Grampositive isolates were resistant to gentamicin and amikacin. Among the Gram-positive isolates, Staphylococcus saprophyticus was the only one resistant to nitrofurantoin. The resistance rate for cefoxitin was $36.4 \%$ among $S$. aureus, and $47 \%$ among Coagulase Negative Staphylococcus (CoNS) isolates (Table 6).

The ES $\beta$ Ls producing isolates were $100 \%$ resistant to all the 3rd generation cephalosporin, cefuroxime, and cefepime. The difference was significant $(p<0.001)$ when 
Table 3 The prevalence of MDR, ES $\beta$ Ls producing and MR (Methicillin resistant) bacteria among uropathogens isolated from the study group

\begin{tabular}{|c|c|c|c|c|}
\hline \multirow[t]{2}{*}{ Isolates } & \multirow[t]{2}{*}{ Number (\%) } & \multicolumn{3}{|c|}{ Frequency and percentage (prevalence) } \\
\hline & & MDR & $E S \beta L$ & MR \\
\hline E. coli & $30(49.2 \%)$ & $17(56.67 \%)$ & $5(16.67 \%)$ & - \\
\hline K.pneumoniae & $2(3.3 \%)$ & $1(50 \%)$ & 0 & - \\
\hline E. cloacae & $1(1.6 \%)$ & $1(100 \%)$ & $1(100 \%)$ & - \\
\hline S. aureus & $11(18 \%)$ & $5(45.45 \%)$ & - & $4(36.36 \%)$ \\
\hline CoNS & $17(27.9 \%)$ & $13(76.47 \%)$ & - & $8(47.06 \%)$ \\
\hline Total & $61(100 \%)$ & $37 / 61(60.65 \%)$ & $6 / 33(18.18 \%)$ & $\begin{array}{l}12 / 28 \\
(42.85 \%)\end{array}$ \\
\hline
\end{tabular}

$M D R$, multi-drug resistant; $E S \beta L$, extended spectrum $\beta$-lactamase; $M R$, methicillin resistant

Table 4 Pregnancy and clinical related factors against significant bacteriuria and MDR bacteria among pregnant women

\begin{tabular}{|c|c|c|c|c|c|c|c|c|}
\hline \multirow[t]{2}{*}{ Variables } & \multicolumn{4}{|c|}{ Significant bacteriuria } & \multicolumn{4}{|c|}{ MDR bacteria } \\
\hline & Yes & No & Total & $\mathrm{p}$-value & Yes & No & Total & $p$-value \\
\hline \multicolumn{9}{|l|}{ Gestation period } \\
\hline$<3$ months & $6(10.9 \%)$ & $49(89.1 \%)$ & 55 & 0.219 & $3(50 \%)$ & $3(50 \%)$ & 6 & 0.808 \\
\hline $3-6$ months & $24(20.2 \%)$ & $95(79.8 \%)$ & 119 & & $15(62.5 \%)$ & $9(37.5 \%)$ & 24 & \\
\hline$>6$ months & $30(15.8 \%)$ & $160(84.2 \%)$ & 190 & & $18(60 \%)$ & $12(40 \%)$ & 30 & \\
\hline Don't know & $1(5 \%)$ & $19(95 \%)$ & 20 & & $1(100 \%)$ & 0 & 1 & \\
\hline \multicolumn{9}{|l|}{ No of Pregnancy } \\
\hline Prim-gravida & $29(18.1 \%)$ & 131 (81.9\%) & 160 & 0.383 & $21(72.4 \%)$ & $8(27.6 \%)$ & 29 & 0.127 \\
\hline Multi-gravida & $32(14.3 \%)$ & $192(85.7 \%)$ & 224 & & $16(50 \%)$ & $16(50 \%)$ & 32 & \\
\hline \multicolumn{9}{|c|}{ No of times giving birth } \\
\hline Nulliparous & $31(17.6 \%)$ & 145 (82.4\%) & 176 & 0.501 & $21(67.7 \%)$ & $10(32.3 \%)$ & 31 & 0.492 \\
\hline Primiparous & $12(12.2 \%)$ & $86(87.8 \%)$ & 98 & & $6(50 \%)$ & $6(50 \%)$ & 12 & \\
\hline Multiparous & $18(16.4 \%)$ & $92(83.6 \%)$ & 110 & & $10(55.6 \%)$ & $8(44.4 \%)$ & 18 & \\
\hline \multicolumn{9}{|l|}{ Hospitalization } \\
\hline Yes & $15(57.7 \%)$ & $11(42.3 \%)$ & 26 & $<0.001$ & $10(66.67 \%)$ & $5(33.3 \%)$ & 15 & 0.807 \\
\hline No & $46(12.8 \%)$ & $312(87.2 \%)$ & 358 & & $27(58.7 \%)$ & $19(41.3 \%)$ & 46 & \\
\hline \multicolumn{9}{|l|}{ History of UTI } \\
\hline Yes & $27(43.5 \%)$ & $35(56.5 \%)$ & 62 & $<0.001$ & $20(74.07 \%)$ & $7(25.93 \%)$ & 27 & 0.099 \\
\hline No & $34(10.6 \%)$ & $288(89.4 \%)$ & 322 & & $17(50 \%)$ & $17(50 \%)$ & 34 & \\
\hline \multicolumn{9}{|l|}{ Antibiotic therapy } \\
\hline Yes & $27(30.7 \%)$ & $61(69.3 \%)$ & 88 & $<0.001$ & $22(81.5 \%)$ & $5(18.5 \%)$ & 27 & 0.007 \\
\hline No & $34(11.5 \%)$ & $262(88.5 \%)$ & 296 & & $15(44.12 \%)$ & 19 (55.88\%) & 34 & \\
\hline \multicolumn{9}{|l|}{ HIV } \\
\hline Yes & $4(30.8 \%)$ & $9(69.2 \%)$ & 13 & 0.135 & $3(75 \%)$ & $1(25 \%)$ & 4 & 1 \\
\hline No & $57(15.4 \%)$ & $314(84.6 \%)$ & 371 & & $34(59.65 \%)$ & $23(40.35 \%)$ & 57 & \\
\hline \multicolumn{9}{|c|}{ Participant status for UTI } \\
\hline Symptomatic & $38(31.1 \%)$ & $84(68.9 \%)$ & 122 & $<0.001$ & $25(65.8 \%)$ & $13(34.2 \%)$ & 38 & 0.433 \\
\hline Asymptomatic & $23(8.8 \%)$ & 239 (91.2\%) & 262 & & $12(52.2 \%)$ & $11(47.8 \%)$ & 23 & \\
\hline
\end{tabular}

The percentage displayed under positive culture and MDR was calculated using the frequency of each classes of the variable group that were enrolled in this study and positive for culture as a denominator, respectively

Italic values means the observed difference is statistically significant $(\mathrm{p}<0.05)$

$M D R$, multi-drug resistant; UTI, urinary tract infection; HIV, human immuno-deficiency virus 
Table 5 Distribution of MDR among uropathogens isolated from the study group

\begin{tabular}{|c|c|c|c|c|c|c|c|}
\hline \multirow[t]{2}{*}{ Isolated organisms } & \multicolumn{6}{|c|}{ Number of drugs affected by the isolate } & \multirow[t]{2}{*}{ Total } \\
\hline & Ro & R1 & $\mathbf{R} 2$ & R3 & R4 & R5 & \\
\hline E. coli $(\mathrm{n}=30)$ & $2(6.67 \%)$ & $1(3.33 \%)$ & $8(26.67 \%)$ & $10(33.33 \%)$ & $2(6.67 \%)$ & $7(23.33 \%)$ & 30 \\
\hline K. pneumoniae $(\mathrm{n}=2)$ & $0(0.0 \%)$ & $0(0.0 \%)$ & $1(50 \%)$ & $1(50 \%)$ & $0(0.0 \%)$ & $0(0.0 \%)$ & 2 \\
\hline E. cloacae $(n=1)$ & $0(0.0 \%)$ & $0(0.0 \%)$ & $0(0.0 \%)$ & $0(0.0 \%)$ & $0(0.0 \%)$ & $1(100 \%)$ & 1 \\
\hline S. aureus $(n=11)$ & $0(0.0 \%)$ & $3(27.27 \%)$ & $3(27.27 \%)$ & $2(18.18 \%)$ & $1(9.09 \%)$ & $2(18.18 \%)$ & 11 \\
\hline CoNS $(n=17)$ & $0(0.0 \%)$ & $2(11.76 \%)$ & $2(11.76 \%)$ & $3(17.65 \%)$ & $1(5.88 \%)$ & $9(52.94 \%)$ & 17 \\
\hline Total (61) & $2(3.28 \%)$ & $6(9.84 \%)$ & $14(22.95 \%)$ & 16 (26.23\%) & $4(6.56 \%)$ & $19(31.15 \%)$ & 61 \\
\hline
\end{tabular}

$\mathrm{RO}$, resistant to none (sensitive to all); R1, resistant to one; R2, resistant to two; R3, resistant to three; R4, resistant to four and R5, resistant to five and more antibiotics tested

compared to resistance rates by non-ES $\beta$ Ls producing isolates. All the ES $\beta$ Ls and most of the non-ES $\beta$ Ls producing strains were resistant to ampicillin and cephalothin. Uropathogens producing ES $\beta$ Ls were sensitive to nitrofurantoin; most of them were susceptible to fluoroquinolones (Table 6).
The only variable that remained an independent factor for the presence of MDR bacterial infection among pregnant women was a prior history of antibiotic therapy $(\mathrm{OR}=5.164,95 \%$ CI 1.226-21.758) (Table 7).

Table 6 Distribution of antibiotic resistance among uropathogens isolated from the study group

\begin{tabular}{|c|c|c|c|c|c|c|c|c|c|}
\hline \multirow{2}{*}{$\begin{array}{l}\text { Antibiotics } \\
\text { tested }\end{array}$} & \multicolumn{5}{|c|}{ Isolated organisms $(n=61)$} & \multirow[t]{2}{*}{ Total (61) } & \multicolumn{3}{|c|}{ Enterobacteriaceae $(n=33)$} \\
\hline & E. coli $(\mathrm{n}=30)$ & $\begin{array}{l}\text { K. } \\
\text { pneumoniae } \\
(n=2)\end{array}$ & $\begin{array}{l}\text { E. } \\
\text { cloacae } \\
(n=1)\end{array}$ & $\begin{array}{l}\text { S. aureus } \\
(n=11)\end{array}$ & CoNS $(n=17)$ & & $\begin{array}{l}\text { Non-ES } \beta \text { Ls } \\
(n=27)\end{array}$ & $E S \beta L s(n=6)$ & p-value \\
\hline$A \cup G$ & 17 (56.67\%) & $1(50 \%)$ & 1 & - & - & 19/33 (57.6\%) & 15 (55.6\%) & $4(66.7 \%)$ & 0.618 \\
\hline FEP & $6(20 \%)$ & 0 & 1 & - & - & $7 / 33(21.2 \%)$ & $1(3.7 \%)$ & $6(100 \%)$ & $<0.001$ \\
\hline CFM & $6(20 \%)$ & 0 & 1 & - & - & $7 / 33(21.2 \%)$ & $1(3.7 \%)$ & $6(100 \%)$ & $<0.001$ \\
\hline $\mathrm{CRO}$ & $5(16.67 \%)$ & 0 & 1 & - & - & $6 / 33(18.2 \%)$ & $0(0.0 \%)$ & $6(100 \%)$ & $<0.001$ \\
\hline FOX & $3(10 \%)$ & 0 & 1 & $4(36.36 \%)$ & $8(47.05 \%)$ & 18/61 (26.2\%) & $1(3.7 \%)$ & $3(50 \%)$ & 0.014 \\
\hline CXM & $5(16.67 \%)$ & 0 & 1 & - & - & 6/33 (18.2\%) & $0(0.0 \%)$ & $6(100 \%)$ & $<0.001$ \\
\hline AMP & 27 (90\%) & $2(100 \%)$ & 1 & - & - & 30/33 (90.9\%) & 24 (88.9\%) & $6(100 \%)$ & 0.392 \\
\hline NAL & $5(16.67 \%)$ & 0 & 1 & - & - & 6/33 (18.2\%) & $2(7.4 \%)$ & $4(66.7 \%)$ & 0.005 \\
\hline $\mathrm{CF}$ & $25(83.33 \%)$ & $2(100 \%)$ & 1 & - & - & 28/33 (84.8\%) & $22(81.5 \%)$ & $6(100 \%)$ & 0.556 \\
\hline CPD & $5(16.67 \%)$ & 0 & 1 & - & - & 6/33 (18.2\%) & $0(0.0 \%)$ & $6(100 \%)$ & $<0.001$ \\
\hline CAZ & $5(16.67 \%)$ & 0 & 1 & - & - & 6/33 (18.2\%) & $0(0.0 \%)$ & $6(100 \%)$ & $<0.001$ \\
\hline NOR & $4(13.33 \%)$ & 0 & 0 & $1(9.1 \%)$ & $8(47.05 \%)$ & 13/61 (21.3\%) & $2(7.4 \%)$ & $2(33.33 \%)$ & 0.142 \\
\hline $\mathrm{F}$ & 0 & 0 & 0 & 0 & $1(5.9 \%)$ & $1 / 61(1.64 \%)$ & $0(0.0 \%)$ & $0(0.0 \%)$ & - \\
\hline CIP & $4(13.33 \%)$ & 0 & 0 & $1(9.1 \%)$ & $8(47.05 \%)$ & 13/61 (21.3\%) & $2(7.4 \%)$ & $2(33.33 \%)$ & 0.142 \\
\hline CTX & $5(16.67 \%)$ & 0 & 1 & - & - & 6/33 (18.2\%) & $0(0.0 \%)$ & $6(100 \%)$ & $<0.001$ \\
\hline GEN & - & - & - & 0 & 0 & $0 / 28(0.0 \%)$ & - & - & - \\
\hline PEN & - & - & - & 10 (90.9\%) & 15 (88.2\%) & 25/28 (89.3\%) & - & - & - \\
\hline $\mathrm{TE}$ & - & - & - & $2(18.18 \%)$ & $9(52.9 \%)$ & 11/28 (39.3\%) & - & - & - \\
\hline COT & - & - & - & $7(63.63 \%)$ & $14(82.35 \%)$ & $21 / 28(75 \%)$ & - & - & - \\
\hline AMK & - & - & - & 0 & 0 & 0/28 (0.0\%) & - & - & - \\
\hline DOX & - & - & - & $2(18.18 \%)$ & $10(58.82 \%)$ & $12 / 28(42.68 \%)$ & - & - & - \\
\hline C & - & - & - & $3(27.27 \%)$ & $9(52.9 \%)$ & $12 / 28(42.68 \%)$ & - & - & - \\
\hline ERY & - & - & - & $2(18.18 \%)$ & $9(52.9 \%)$ & 11/28 (39.3\%) & - & - & - \\
\hline
\end{tabular}

Italic values means the observed difference is statistically significant $(\mathrm{p}<0.05)$

"_" Not done; AUG, amox-clavulanic acid; FEP, cefepime; CFM, cefixime; CRO, ceftriaxone; FOX, cefoxitin; CXM, cefuroxime; AMP, ampicillin; NAL, nalidixic acid; CF, cephalothin; CPD, cefpodoxime; CAZ, ceftazidime; NOR, norfloxacin; F, nitrofurantoin; CIP, ciprofloxacin; CTX, cefotaxime; PEN, penicillin; TE, tetracycline; COT, cotrimoxazole; AMK, amikacin; DOX, doxycycline; C, chloramphenicol, and ERY, erythromycin 
Table 7 Bi-variable and multi-variable analysis of factors associated with the presence of MDR bacteria

\begin{tabular}{|c|c|c|c|c|}
\hline \multirow[t]{2}{*}{ Variable } & \multicolumn{2}{|c|}{ MDR } & \multirow[t]{2}{*}{$\operatorname{COR}(95 \% \mathrm{Cl})$} & \multirow[t]{2}{*}{ AOR $(95 \% \mathrm{Cl})$} \\
\hline & Yes & No & & \\
\hline \multicolumn{5}{|l|}{ Occupation } \\
\hline House wife & 16 & 6 & $5.867(1.427-24.113)$ & $6.544(1.005-42.616)$ \\
\hline Farmer & 7 & 2 & $7.700(1.159-51.171)$ & $4.058(0.277-59.49)$ \\
\hline Merchant & 5 & 4 & $2.750(0.509-14.860)$ & $1.781(0.197-16.066)$ \\
\hline Employed & 5 & 11 & 1 & \\
\hline Daily labourer & 2 & 1 & $4.400(0.319-60.614)$ & $1.965(0.40-97.385)$ \\
\hline Others & 2 & 0 & - & - \\
\hline \multicolumn{5}{|l|}{ Education } \\
\hline Not read and write & 8 & 6 & $2.000(0.456-8.777)$ & $1.442(0.169-12.282)$ \\
\hline Primary & 14 & 3 & $7.000(1.386-35.345)$ & $2.558(0.287-22.089)$ \\
\hline Secondary & 9 & 6 & $2.250(0.522-9.697)$ & $0.915(0.135-6.194)$ \\
\hline College and above & 6 & 9 & 1 & \\
\hline \multicolumn{5}{|l|}{ No of pregnancy } \\
\hline Prim-gravida & 21 & 8 & 1 & \\
\hline Multi-gravida & 16 & 16 & $0.381(0.131-1.110)$ & $0.414(0.092-1.855)$ \\
\hline \multicolumn{5}{|l|}{ History of UTI } \\
\hline Yes & 20 & 7 & $2.857(0.959-8.516)$ & $2.687(0.599-12.052)$ \\
\hline No & 17 & 17 & 1 & \\
\hline \multicolumn{5}{|l|}{ Antibiotic therapy } \\
\hline Yes & 22 & 5 & $5.573(1.706-18.205)$ & $5.164(1.226-21.758)^{*}$ \\
\hline No & 15 & 19 & 1 & \\
\hline
\end{tabular}

Italic value means there is a statistical significance between independent and dependent variables ( $95 \% \mathrm{Cl}$ excludes the null value, which is 1)

$\mathrm{COR}$, crude odd ratio; $\mathrm{AOR}$, adjusted odd ratio; $\mathrm{Cl}$, confidence interval

$\left.{ }^{*}\right)$ p-value $<0.05$

\section{Discussion}

The high prevalence of UTI during pregnancy and fear of its complication on both mothers and their baby $[6,26]$ encourages the irrational use of antibiotics [38], especially in the developing world where empirical treatment is prevalent. Knowing the prevalence of drug-resistant uropathogens among pregnant women could help the clinicians to improve the wise use of antibiotics during pregnancy.

The prevalence of UTI $(15.9 \%)$ in this study was in agreement with previous studies in eastern Ethiopia (14\%) [33] and in Tanzania (14.6\%) [39]. But it was higher than the studies conducted in Bahir Dar (9.5\%) by Tazebew D et al. [31] and in Gondar (10.4\%) by Alemu et al. [29]. This difference might be due to the higher proportion of symptomatic study participants in the present study.

The most prevalent uropathogen identified was E. coli 49.2\%, followed by CoNS $27.9 \%$ and S. aureus $18.03 \%$. Previous reports from different regions of Ethiopia have also reported similar findings [29, 31, 33]. The result, however, was slightly different from the study from Hawassa [28], where CoNS were frequently isolated. This difference might be due to the difference in hygienic practices between study participants and climate and temperature factors.

In the present study, the prevalence of MDR bacteria was $60.65 \%$. This study reported a lower prevalence than previous studies in the same study area, $68 \%$ in 2002 [40], and $95 \%$ in 2012 [29]. The lower prevalence may be due to differences in MDR definition and/ or the antibiotics used for AST. Our prevalence was higher than the study result from Pakistan, where MDR prevalence was $37.9 \%$ [41]. The lower prevalence seen in Pakistan may be due to the presence of male participants in the study.

The present study was also aimed to assess the prevalence of ES $\beta$ Ls production among Enterobacteriaceae. Hence, the prevalence of ES $\beta$ Ls was $18.2 \%$. This prevalence was lower than previous reports in Ethiopia, which was between 25 and 38.4\% [42-44]. Reasonably, difference in study setting, sampling protocol and study population could have an impact on the isolation rate of ES $\beta$ Ls. Likewise, the finding of this study was lower than the study done in India (25.2\%) by Selvakumar et al. [45]. On the other hand, it was higher than the study done in Nepal (7.3\%) by Thapa et al. [46] and Pakistan (5.8\%) by Iqbal et al. [41]. This difference of prevalence might be due to the difference in number of bacterial isolates, and geographical area.

At species level, this study revealed that the prevalence of ESBLs producing E.coli was $16.7 \%$ and it is incompatible with a report by Olufunke et al. in Nigeria [21]. This prevalence was also lower than the previous study results in Ethiopia. For instance, 36\% and $28.2 \%$ of ES $\beta \mathrm{L}$ producing E. coli was identified in Jimma by 2012 [42] and 2015 [43], respectively.

In the present study, about $90 \%, 84.8 \%$, and $57.6 \%$ of gram-negative uropathogens were resistant to ampicillin, cephalothin, and augmentin, respectively. Previous reports from different parts of Ethiopia also showed a high resistance rate to ampicillin and augmentin [30, 31]. The possible explanation of ampicillin and augmentin resistance might be due to their extensive use in the health facilities as this may boost the selection of uropathogens harboring the $\beta$-lactamase enzyme, which can hydrolyze penicillin.

We reported that drugs like nitrofurantoin, gentamicin, and amikacin were effective against uropathogens, followed by norfloxacin and ciprofloxacin. Thapa et al. [46] reported the same antibiotics as the effective drugs to treat bacterial UTIs. The current study also reported that ES $\beta$ Ls producing bacterial uropathogens were resistant to 9 out of 15 antibiotics tested, especially to 3rd generation cephalosporins. This finding was in line with 
previous studies done by Onwuezobe et al. in Nigeria [47] and by Kumar Yadav et al. in Nepal [48]. This higher antibiotic resistance rate among ES $\beta$ Ls producing isolates may be because of the presence of plasmid carrying genes other than those coding for ES $\beta$ Ls, which are responsible for resistant to other classes of antibiotics like fluoroquinolones.

In the present study, all ES $\beta$ Ls producing isolates were sensitive to the drug nitrofurantoin. The same thing happened in Nepal by Thapa et al. [46] and Sri Lanka by Dissanayake et al. [49]. This similarity in nitrofurantoin sensitivity rate between studies might be because of its narrow range of clinical indications, which results in less usage compared to other UTI drugs.

History of antibiotic usage was the only variable associated with the presence of MDR uropathogens. The previous study in Ethiopia also reported the use of antibiotics as a risk factor for acquiring MDR bacteria [40]. Other studies were also reported antibiotic usage as a risk factor for the presence of ES $\beta$ Ls producing strains, which are usually MDR [50, 51].

\section{The limitation and strength of the study}

The study was done in the hospital setting so that the result may not be representative of other pregnant women attending other health sectors in the same area. Associated factors for MDR bacterial infection were not fully addressed because of the absence of participants with factors like catheterization, and chronic diseases like diabetes mellitus. The number of isolates was small, and this may affect the estimation of the prevalence of ES $\beta \mathrm{L}$ producing strains among pregnant women.

\section{Conclusion}

Antibiotics like nitrofurantoin, ciprofloxacin, and norfloxacin were effective against gram-negative uropathogens, including ES $\beta \mathrm{L}$ producers. Gentamicin, amikacin, and nitrofurantoin were effective against staphylococcus species, which causes UTI. The prevalence of MDR was high among uropathogens, which calls for the use of AST results to treat UTI during pregnancy. The presence of Multi-drug resistant bacterial infection during pregnancy was associated with prior antibiotic therapy. The isolation of ES $\beta$ Ls producing uropathogens and methicillin-resistant staphylococcus species in this study calls for the need of periodic and continuous follow-up of antibiotic usage during pregnancy. Moreover, conducting molecular studies will help to characterize the various drug-resistant strains.

\section{Abbreviations}

ABR: Antibiotic resistance; ANC: Anti-natal care; AST: Antimicrobial Susceptibility Testing; ATCC: American Type Culture Collection; CLSI: Clinical and
Laboratory Standards Institute; CoNS: Coagulase negative Staphylococcus; ESßLs: Extended-spectrum $\beta$-lactamases; MDR: Multi-drug resistant; MR: Methicillin resistant; MRSA: Methicillin resistant Staphylococcus aureus; SOPs: Standard Operating Procedures; SPSS: Statistical Package for Social Sciences; UTIs: Urinary tract infections.

\section{Acknowledgements}

The authors would like to acknowledge the University of Gondar, School of Medicine and Health Sciences, and Amhara regional health bureau for supporting this project. The authors are grateful to the staff who are working under the microbiology lab and teaching hospital of the University of Gondar; extend their special thanks to both study participants and data collectors.

\section{Authors' contributions}

SB conception of the research idea, study design, data collection, analysis and interpretation, and manuscript write-up. FM data analysis and interpretation and supervision. DE data collection and analysis. SE: Data analysis and interpretation, supervision, and manuscript write-up. All authors read and approved the final manuscript.

\section{Funding}

The study was supported by Mega project of the University of Gondar in Reference number of VP/RCS/05/192/2015

\section{Availability of data and materials}

The datasets used and/or analyzed during the current study are available from the corresponding author on reasonable request.

\section{Ethics approval and consent to participate}

This research was ethically cleared and approved by the University of Gondar, School of Biomedical and Laboratory Sciences ethical review committee. Written and informed consent was obtained from study participants after explaining the purpose and aim of the study. The result from the study participants was sent to their physicians for appropriate treatment.

\section{Consent for publication}

Not applicable.

\section{Competing interests}

The authors have declared that they have no competing interests.

Received: 7 October 2019 Accepted: 25 May 2020

Published online: 03 June 2020

\section{References}

1. Sheerin NS. Urinary tract infection. Medicine. 2011;39(7):384-9.

2. Grabe M, Bartoletti R, Johansen BTE, Cai T, Cek M, Köves B, Naber KG, Pickard RS, Tenke P, Wagenlehner F, et al. Guidelines on urological infections. Netherlands: European Association of Urology; 2015. p. 86.

3. Cornelissen CN, Fisher BD, Harvey RA. Lippincott's illustrated reviews: microbiology 3rd edn; 2013.

4. McGuire L. A seat on the aisle, please! the essential guide to urinary tract problems in women. Mayo Clin Proc. 2007;82(1):130.

5. Urinary tract infections in pregnancy: practice essentials, pathophysiology, etiology. (http://emedicine.medscape.com/article/452604-overv iew\#a4).

6. Mazor-Dray E, Levy A, Schlaeffer F, Sheiner E. Maternal urinary tract infection: is it independently associated with adverse pregnancy outcome? J Matern Fetal Neonatal Med. 2009:22(2):124-8.

7. Mittendorf R, Williams MA, Kass EH. Prevention of preterm delivery and low birth weight associated with asymptomatic bacteriuria. Clin Infect Dis. 1992;14(4):927-32

8. Minassian C, Thomas SL, Williams DJ, Campbell O, Smeeth L. Acute maternal infection and risk of pre-eclampsia: a population-based case-control study. PLOS ONE. 2013;8(9):e73047.

9. Nicolle LE, Bradley S, Colgan R, Rice JC, Schaeffer A, Hooton TM. Infectious Diseases Society of America guidelines for the diagnosis and treatment of asymptomatic bacteriuria in adults. Clin Infect Dis. 2005;40(5):643-54. 
10. Emamghorashi F, Mahmoodi N, Tagarod Z, Heydari ST. Maternal urinary tract infection as a risk factor for neonatal urinary tract infection. Iran J Kidney Dis. 2012;6(3):178-80.

11. Mazor-Dray E, Levy A, Schlaeffer F, Sheiner E. Maternal urinary tract infection: is it independently associated with adverse pregnancy outcome? J Maternal Fetal Neonatal Med. 2009;22(2):124-8.

12. Hines AG, Rupp ME, Schooneveld TCV. Urinary tract infection and asymptomatic bacteriuria guidance. Omaha, Nebraska: Nebraska Medical Center; 2014

13. Merseburger AS, Markus AK, Moul JW. Urology at a Glance. Berlin: Springer; 2014.

14. Microbiology TAAO Antibiotic resistance: an ecological perspective on an old problem. 1752 N Street, NW, Washington, DC 20036: American Academy of Microbiology; 2009.

15. O'Neill J. Tackling Drug-resistance infections globally: final report and recommondations. London: Wellcome Trust \& HM Government; 2016.

16. Read AF, Woods RJ. Antibiotic resistance management. Evol Med Public Health. 2014;2014(1):147.

17. Wiesch ZPA, Kouyos R, Engelstadter J, Regoes RR, Bonhoeffer S. Population biological principles of drug-resistance evolution in infectious diseases. Lancet Infect Dis. 2011;11(3):236-47.

18. Rawat D, Nair D. Extended-spectrum $\beta$-lactamases in Gram Negative Bacteria. J Global Infect Dis. 2010;2(3):263-74.

19. Thenmozhi S, Moorthy K, Sureshkumar B, Suresh M. Antibiotic resistance mechanism of ESBL producing Enterobacteriaceae in clinical field: a review. Int J Pure Appl Biosci. 2014;2(3):207-26

20. Paterson DL, Bonomo RA. Extended-spectrum beta-lactamases: a clinical update. Clin Microbiol Rev. 2005;18(4):657-86.

21. Olufunke OA, Abiodun AO, Dunah FC. Extended spectrum beta-lactamase-producing uropathogenic escherichia coli in pregnant women diagnosed with urinary tract infections in South-Western Nigeria. J Mol Biol Res. 2014;4(1):34-41.

22. Seale J, Millar M. Perinatal vertical transmission of antibiotic-resistant bacteria: a systematic review and proposed research strategy. BJOG Int J Obstet Gynaecol. 2014;121(8):923-8.

23. Gilstrap LC 3rd, Ramin SM. Urinary tract infections during pregnancy. Obstet Gynecol Clin North Am. 2001;28(3):581-91.

24. Denkel LA, Schwab F, Kola A, Leistner R, Garten L, von Weizsacker K, Geffers C, Gastmeier P, Piening B. The mother as most important risk factor for colonization of very low birth weight (VLBW) infants with extendedspectrum beta-lactamase-producing Enterobacteriaceae (ESBL-E). J Antimicrob Chemother. 2014:69(8):2230-7.

25. Rettedal S, Lohr IH, Bernhoff E, Natas OB, Sundsfjord A, Oymar K. Extended-spectrum beta-lactamase-producing Enterobacteriaceae among pregnant women in Norway: prevalence and maternal-neonatal transmission. J Perinatol. 2015:35(11):907-12

26. Amiri M, Lavasani Z, Norouzirad R, Najibpour R, Mohamadpour M, Nikpoor AR, Raeisi M, Zare Marzouni H. Prevalence of urinary tract infection among pregnant women and its complications in their newborns during the birth in the hospitals of Dezful City, Iran, 2012-2013. Iran Red Crescent Med J. 2015:17(8):e26946.

27. Fircanis SM, McKay MR. Recognition and Management of Extended Spectrum Beta Lactamase Producing Organisms (ESBL). In: Fulton ATM, editor. Geriatrics for the practicing physician, vol. 93. Rhode Island: The warren alpert medical school of brownuniversity; 2010. p. 161-2.

28. Tadesse E, Teshome M, Merid Y, Kibret B, Shimelis T. Asymptomatic urinary tract infection among pregnant women attending the antenatal clinic of Hawassa Referral Hospital, Southern Ethiopia. BMC Res Notes. 2014;7:155.

29. Alemu A, Moges F, Shiferaw Y, Tafess K, Kassu A, Anagaw B, Agegn A. Bacterial profile and drug susceptibility pattern of urinary tract infection in pregnant women at University of Gondar Teaching Hospital, Northwest Ethiopia. BMC Res Notes. 2012;5:197.

30. Beyene G, Tsegaye W. Bacterial uropathogens in urinary tract infection and antibiotic susceptibility pattern in Jimma university specialized hospital, Southwest Ethiopia. Ethiop J Health Sci. 2011;21(2):141-6.

31. Demilie T, Beyene G, Melaku S, Tsegaye W. Urinary bacterial profile and antibiotic susceptibility pattern among pregnant women in North West Ethiopia. Ethiop J Health Sci. 2012;22(2):121-8.

32. Ferede G, Yismaw G, Wondimeneh Y, Sisay Z. The prevalence and antimicrobial susceptibility pattern of bacterial uropathogens isolated from pregnant women. Eur J Exp Biol. 2012;2(5):1497-502.
33. Derese B, Kedir H, Teklemariam Z, Weldegebreal F, Balakrishnan S. Bacterial profile of urinary tract infection and antimicrobial susceptibility pattern among pregnant women attending at Antenatal Clinic in Dil Chora Referral Hospital, Dire Dawa, Eastern Ethiopia. Ther Clin Risk Manag. 2016;12:251-60.

34. World Health Organization. Antibiotic resistance: global report on surveillance. Geneva: World Health Organization; 2014

35. Cheesbrough M. District laboratory practice in tropical countries_-part 2. 2nd ed. New York: Cambridge University Press; 2006.

36. Clinical and Laboratory Standards Institute. Performance standards for antimicrobial susceptibility testing; twenty-fourth informational supplement. CLSI document M100-S24. Wayne: Clinical and Laboratory Standards Institute; 2014.

37. Clinical and Laboratory Standards Institute. Performance standards for antimicrobial susceptibility testing. CLSI supplement M100, vol. 27. Wayne: Clinical and Laboratory Standards Institute; 2017.

38. Berard A, Santos F, Ferreira E, Perreault S. Urinary tract infections during pregnancy. In: Tenke DP, editor. Urinary tract infections. London: InTech; 2011. p. 360.

39. Masinde A, Gumodoka B, Kilonzo A, Mshana SE. Prevalence of urinary tract infection among pregnant women at Bugando Medical Centre, Mwanza, Tanzania. Tanzania J Health Res. 2009;11(3):154-9.

40. Moges F, Mengistu G, Genetu A. Multiple drug resistance in urinary pathogens at Gondar College of Medical Sciences Hospital, Ethiopia. East African Med J. 2002;79(8):415-9.

41. Iqbal R, Majid A, Alvi IA, Hayat A, Andaleeb F, Gul S, Irfan S, Rahman MU. Multiple drug resistance and ESBL production in bacterial urine culture isolates. Am J BioSci. 2014;2(1):5-12.

42. Mulualem Y, Kasa T, Mekonnen Z, Suleman S. Occurrence of extended spectrum beta (b)-lactamases in multidrug resistant Escherichia coli isolated from a clinical setting in Jimma university specialized hospital, Jimma, southwest Ethiopia. East Afr J Public Health. 2012;9(2):58-61.

43. Siraj SM, Ali S, Wondafrash B. Extended-spectrum $\beta$-lactamase production in Klebsiella pneumoniae and Escherichia coli at Jimma University Specialized Hospital, South-West, Ethiopia. Mol Microb Res. 2015;5(1):1-9. https ://doi.org/10.5376/mmr.2015.04.0001.

44. Mulisa G, Selassie L, Jarso G, Shiferew T, Zewdu A, Abebe W, Belachew F, Sewunet T. Prevalence of extended spectrum beta-lactamase producing Enterobacteriaceae: a cross sectional study at Adama Hospital, Adama, Ethiopia. J Emerg Infect Dis. 2016;1(1):1-6.

45. Selvakumar B, Jasmine R. Prevalence \& antibacterial resistance of esbls among pregnant women with uti. Int J Pharm Sci Res. 2011;2(11):2846.

46. Thapa R, Lamichhane P, Banjara MR, Acharya GP. Prevalence of extended spectrum betalactamse producing uropathogens in pregnant women. Asian J Pharm Clin Res. 2015;8(1):207-10.

47. Onwuezobe A, Orok F. Extended spectrum beta-lactamase producing Uropathogens in Asymptomaticpregnant women attending antenatal care in an urban community secondary health facility. Afr J Clin Exp Microbiol. 2015;16(2):49-53.

48. Yadav KK, Adhikari N, Khadka R, Pant AD, Shah B. Multidrug resistant Enterobacteriaceae and extended spectrum $\beta$-lactamase producing Escherichia coli: a cross-sectional study in National Kidney Center, Nepal. Antimicrob Resist Infect Control. 2015;4(1):42.

49. Dissanayake DMBT, Fernando SSN, Chandrasiri N. The distribution and characteristics of Extended-Spectrum $\beta$-Lactamase(ESBL) producing Escherichia coli and Klebsiella species among urinaryisolates in atertiary care hospital. Sri Lanka J Infect Dis. 2012;2(2):30-6.

50. Colodner R, Rock W, Chazan B, Keller N, Guy N, Sakran W, Raz R. Risk factors for the development of extended-spectrum beta-lactamaseproducing bacteria in nonhospitalized patients. Eur J Clin Microbiol Infect Dis. 2004;23(3):163-7

51. Lautenbach E, Patel JB, Bilker WB, Edelstein PH, Fishman NO. Extendedspectrum beta-lactamase-producing Escherichia coli and Klebsiella pneumoniae: risk factors for infection and impact of resistance on outcomes. Clin Infect Dis. 2001;32(8):1162-71.

\section{Publisher's Note}

Springer Nature remains neutral with regard to jurisdictional claims in published maps and institutional affiliations. 